\title{
Analysis of the Applied Talents Cultivation Mode of Mathematics and Applied Mathematics
}

\author{
Rong Miao \\ Weinan Normal University, Weinan, 714000, China
}

Keywords: Mathematics and Applied Mathematics; Applied Talents; Training Modes

\begin{abstract}
As Chinese higher education enters the mass education from elite education, the scale of higher education in our country ranks first in the world, but the ensuing employment problem for college graduates is that students not only have unsatisfied initial employment, professional counterpart rates, The quality of employment is not satisfactory, but the relevant survey data shows that the vast number of enterprises and institutions on the demand for talent is very strong, especially the large gap between skilled personnel, this phenomenon proves that Chinese higher education personnel training and social needs There is a big difference. The root cause of this problem is that the talent supply and demand are misplaced in the personnel training standards. Therefore, the major colleges and universities should change the concept of talent training according to their own actual conditions, and the traditional knowledge-based personnel training will gradually focus on the training of applied talents in order to improve the adaptability of students, comprehensive competitiveness. The paper analyzes the training of applied talents in mathematics and applied math.
\end{abstract}

\section{Introduction}

Applied talents mainly refer to the high-quality talents with high quality of physical, psychological, academic and abilities. They have the ability to comprehensively apply multidimensional knowledge and can engage in more complicated social practices and make their own creative contributions to social progress to contribute. Thus it can be seen that applied talents are characterized by diversified knowledge structure, high comprehensive literacy level and secondary innovation and knowledge transformation ability.

\section{The Problems of Math and Applied Math Major Application-Oriented Personnel Training}

Specifically, the cultivation of applied talents in math and applied mathematics in colleges and universities in our country still has the following problems:

However, with the continuous deepening of Chinese education system reform and the change of recruitment form of teachers, the number of teachers in all primary and secondary schools and even in higher education institutions tends to be saturated. With the slowdown of population growth in China, the students' source is declining and the demand for teachers in society is also declining. Now teachers' posts are no longer the prerogatives of normal students. Students who graduate from other non-teacher colleges should be able to pass teachers' qualifying examination can also enter the teaching post, virtually increase the employment pressure of professional teachers. Under the severe employment situation, some students pay insufficient attention to the study of math and applied math professional knowledge and skills, lacking the courage and confidence to compete.

Mathematics and Applied Mathematics major to develop all-round development of application, compound, skilled and innovative talents as the main goal, follow the "thick foundation, wide caliber, strong ability, high-quality" training strategy. However, with the popularization of popular education, the enrollment of mathematics and applied math has also been expanded. Although some colleges and universities split their courses on math and applied mathematics, they are divided into teaching and education, finance and statistics, information technology and computer different professional aspects, but as a whole, there are still some problems in the curriculum such as 
inaccurate target orientation and weak application type, which can not meet the demand of talent market for applied talents.

At present, many schools of mathematics and applied mathematics teaching methods still remain in the teacher to explain the students accepted the traditional teaching level, teaching methods dull, a single educational thinking, teaching process is too focused on students grasp the basics, ignoring the practice of students Ability and innovative thinking. As a result, classroom teaching only emphasizes theory and does not attach importance to practice. Most students have a serious lack of innovative thinking and skills training, which makes students not only lack of interest in learning, but also not clear about their learning goals.

\section{The Strategy to Improve Math and Applied Math Applied Talents Training Quality}

For math and applied math applied talents training problems, it is recommended to improve from the following aspects:

The current classroom teaching is still the main means of personnel training, so we must continue to optimize teaching methods, through scientific and effective classroom teaching to improve teaching quality. First, adopt a variety of teaching methods. Since the development of teaching technology, many kinds of teaching methods have been applied more and more widely in the field of education, such as task teaching, situational teaching, problem teaching and stratified teaching methods. Teachers should choose appropriate teaching according to the actual situation of students method. In addition, we must also make full use of various teaching methods in the classroom to improve the fun and vividness of classroom teaching. In particular, math and applied math have a lot of abstraction and information richness. They can not get good teaching effects only by traditional chalkboards. They also need to demonstrate their visual and visual knowledge to students in various forms such as PPT, slideshow, audio and video. Diverse teaching methods can stimulate students' interest in learning and improve their learning. That is, in the process of mathematics teaching, teachers should fully consider the cognitive structure, knowledge structure, emotional experience and other factors of the students, recognize that the students are the reality of the learning main body, not only emphasize the knowledge structure and logical system of teaching contents during the lesson preparation, It is necessary to analyze the learning characteristics and learning phenomena of students so as to return the teaching of mathematics and applied mathematics to life and improve the maneuverability and reality of mathematics and applied mathematics knowledge. The traditional math and applied math expertise is mainly based on the theoretical knowledge of formulas, reasoning and computing, but lacks the knowledge of relevance to socio-economic and natural sciences. The teacher should optimize the teaching content, guide the students to obtain the information from the actual problems, and integrate the mathematical modeling thinking into the mathematics and applied mathematics teaching so as to improve students' abilities of analyzing and solving problems.

In practical talents training mode, the construction of practical teaching system is an important way to ensure the quality of personnel training. Therefore, the practical teaching system should be guided by the needs of society and construct a teaching mode that suits the needs of regional economic development. On the one hand, the actual teaching process can be appropriate compression of theoretical teaching, improve the proportion of practical teaching. When constructing curriculum modules, the knowledge system is divided into four modules: "basic application", "professional development", "scientific and technological activities" and "off-campus practice" to change the subordinate position of practice teaching in the traditional teaching system. Improve the practice teaching system of quality control system, to practice all aspects of teaching to be standardized to ensure the quality of teaching. On the other hand, we should set up an open practice teaching platform. Colleges and universities should abide by the principle of "resource integration, overall planning and integrated functions" and set up an open practice teaching platform for the cultivation of applied talents in light of their own actual conditions so as to create an autonomous learning, autonomous practice, self-experience and freedom creation for students Learning environment, to promote practical teaching from the laboratory to an internship and 
research platform, to meet students' basic knowledge and to improve their practical skills and practical innovation ability. Practical teaching center with mathematical modeling and experiment, teacher skills training, statistical analysis and calculation of a number of functions, not only to meet the basic needs of students, but also through the platform to complete professional development, in order to consolidate students' professional theoretical knowledge, training Its practice of innovation provides good conditions.

The main purpose of evaluation and assessment is to make comprehensive and objective feedback on the learning effect of the students. Teachers make timely adjustments to the teaching strategies according to the evaluation results. Therefore, a scientific and effective evaluation mechanism is necessary to ensure the quality of applied talents. The more diversified the evaluation methods in practical teaching, the more comprehensive and objective the evaluation of students. The actual evaluation process, according to the characteristics of the course on the students' daily scores, review scores, test paper scores set different scores, of which $30 \%$ of daily scores, the main evaluation indicators include class attendance, question answering and job completion , Etc .; review scores of $10 \%$, by the end of the period by the students to design their own papers, their answer, the teacher score on the paper content, this review method not only reduce the psychological burden on students, and will stimulate their enthusiasm for review; The main content of the paper is to evaluate the ability of students to apply mathematical thinking and method to solve specific problems. In addition, an additional index of innovation ability can be added to evaluate students 'ability to apply. The evaluation index includes students' participation in all kinds of science and technology Activity results obtained can also be students in the study of a course issued by the investigation reports or dissertations, such as the use of derivatives and integral mathematical analysis of knowledge such as housing prices, interest rates, investment and other hot issues analysis, the formation of research reports or papers, which The assessment method can really comment whether students will be transformed into knowledge capacity.

The teacher is an important medium to cultivate the applied talents in the process of training applied talents. It can be said that the teacher's personal qualities and professional abilities directly determine the training quality of the qualified personnel. Therefore, it is necessary to strengthen the construction of the teaching staff. Teachers of mathematics and applied mathematics should not only have strong teaching ability, practical ability to guide, but also have innovative educational concepts and a strong combination of qualities, in particular, through the following measures to create a high-quality teachers Team: First of all, pay attention to the cultivation and introduction of academic leaders and academic leaders, establish a sound training mechanism for academic leaders and create favorable training conditions for them; improve the salary and welfare structure of colleges and universities and retain qualified personnel to attract talents. Secondly, in the school through the selection of the form for those responsible, motivated subjects to enter the young teachers to provide more convenience, so that they have more education, advanced knowledge of the field of exchange of knowledge and training opportunities to improve their professional ability and overall quality. In addition, but also to strengthen the contact between teachers and enterprises, in-depth understanding of enterprise positions at the enterprise real employment needs, improve the teaching ability of teachers. Finally, schools also need to improve their examination and evaluation methods, strengthen the construction and improvement of teachers' assessment system, encourage teachers to keep making progress through a healthy job competition mechanism, continuously enrich their teaching content and reform their teaching methods so as to enhance the overall quality of teachers.

\section{Conclusion}

In short, math and applied mathematics major in colleges and universities to train professional teachers or outstanding researchers as the main goal, math and applied mathematics teaching must be reformed in order to better adapt to the current education system. However, the saturation of teachers' teams increases the employment pressure of math and applied math graduates, so the urgency of math and applied mathematics teaching reform becomes more prominent. The 
cultivation of applied talents is to strengthen students' comprehensive quality and professional ability as the core, not only to consider the basic knowledge of learning, but also to turn knowledge into ability to guide practice. Under the model of applied talents training, students can be provided with more opportunities in real life to broaden their employment scope and promote their growth and career development after graduation. Therefore, colleges and universities should attach importance to the cultivation of applied talents, constantly reform math and applied mathematics courses, and gradually perfect the application-oriented talents training mode of math and applied math that meet the needs of society, so as to deliver high-quality applied talents to the society.

\section{References}

[1] Cao Ming. Application-based undergraduate innovation and entrepreneurship training mode [J]. China University Teaching, 2016 (11).

[2] Bei Dunrong. On the Talent Cultivation Model and Reform of Colleges and Universities [J]. China University Teaching, 2016 (11).

[3] Wang Ping-xiang, Tang Tie-jun, Liu Wei, Shen Pei. Investigation on Constructing Innovative Experimental Zone of Talent Training Mode [J]. Journal of Chinese University, 2017 (5).

[4] Li Juxian. Talents Training Mode Innovation Experimental Zone Construction Path and Development Strategy [J]. National School of Education Administration, 2017 (3).

[5] Pang Guobin, Liu Guijun. Construction of General Education Curriculum: A Problem to be Clarified and Studied [J]. Journal of Dalian University, 2014 (2).

[6] Ma Xiaoyan, Exploration and Practice of Applied Talents Training Model under Pluralistic Needs [J]. Journal of Taishan University, 2015 (6). 